\title{
ARTIKELEN
}

\section{Machtenscheiding en rechtsstaat (of rechtersstaat?) na Urgenda}

\author{
P.P.T. Bovend'Eert
}

\section{Inleiding}

In de nasleep van het Urgenda-arrest van de Hoge Raad ${ }^{1}$ zijn de emoties bij sommigen hoog opgelopen. Forum voor Democratie-leider Thierry Baudet waarschuwt voor de sluipende machtsgreep die de rechterlijke macht in Nederland onderneemt. De democratie wordt zijns inziens steeds verder ondermijnd. Een heerschappij van rechters ('dikastocratie') zou in toenemende mate de achilleshiel van de rechtsstaat vormen.

Marc de Werd ziet in de uitlatingen van Baudet een poging van populisten om rechters verdacht te maken. In een opiniestuk in de Volkskrant kwalificeert hij de opmerkingen van Baudet als misplaatste angst voor rechters ('dikastofobie'). De opmerkingen van Baudet stelt hij op één lijn met de handelwijze van de populistische regering in Polen, hun karaktermoord op rechters en de daaruit voortvloeiende rechtsstatelijke misstanden. De vrees voor een 'gouvernement des juges' (rechterlijk activisme) is volgens De Werd geen reële angst. Want rechters hanteren anders dan politici geen beleidsmatige vergezichten. 'Zij denken niet in termen van macht, maar zoeken, binnen de grenzen van het recht, naar oplossingen van rechtsvragen in individuele zaken', zo betoogt De Werd in zijn opiniestuk. ${ }^{2}$

Het debat over het Urgenda-arrest beperkt zich niet tot dergelijke emotioneel getinte betogen. Vele rechtswetenschappelijke beschouwingen zijn inmiddels gewijd aan het arrest. ${ }^{3}$ Grofweg zijn in deze beschouwingen twee typen benaderingen te onderscheiden. Enerzijds krijgt het Urgenda-arrest een warm welkom bij diegenen die een groot vertrouwen hebben in de rechtsvormende taak van de Hoge Raad. In

2 M. de Werd, “Framing” van rechters bedreigt onze rechtsstaat', de Volkskrant 3 februari 2020.

3 Een greep uit het ruime aanbod: E.R. de Jong, 'Urgenda en de beoordeling van macro-argumenten', MvV 2019, p. 133 e.v.; R. Schutgens, 'Urgenda en de Trias', NJB 2015, p. 2270 e.v.; G. Boogaard, 'Urgenda en de rol van de Rechter', AA 2016, p. 26 e.v.; O. Spijkers, 'Urgenda tegen de Staat der Nederlanden', AA 2019, p. 191; M.A. Loth, 'Eenheid in gelaagdheid’, AA 2018, p. 335 e.v.; R. van Gestel \& M. Loth, 'Urgenda: roekeloze rechtspraak of rechtsvinding 3.0?', NJB 2015, p. 2598 e.v.; L.F.M. Besselink, 'Rechter en politiek: machtenscheiding in de Urgenda-zaak', TvCR 2020, p. 18 e.v.; M.A. Loth, 'Urgenda, ieder het zijne', RMThemis 2020, p. 89 e.v.; A.E.M. Leijten, 'Urgenda. Het recht op een rechtvaardiging en hoe de Hoge Raad in Urgenda de bescherming van fundamentele rechten serieus neemt', RMThemis 2020, p. 94 e.v.; R. van der Hulle, Naar een Nederlandse political question-doctrine? (diss. Nijmegen), Deventer: Wolters Kluwer 2020; R. van Gestel \& M. Loth, 'De legitimiteit van rechterlijke rechtsvorming', AA 2020, p. 885 e.v.; G. Boogaard \& R. Schutgens, 'Grensrechters in eigen zaak', $A A$ 2020, p. 888. 
de terminologie van Vranken zien zij de wetgever en de Hoge Raad als 'partners in law business'. ${ }^{4}$ Anderzijds wordt het Urgenda-arrest door sommigen, vooral van staatsrechtelijke huize, met de nodige scepsis bejegend. ${ }^{5}$ Begeeft de Hoge Raad zich met het reductiebevel van het realiseren van $25 \% \mathrm{CO}_{2}$-uitstoot in 2020 niet op het politieke domein van regering en parlement? Is dit arrest wel te rijmen met de machtenscheiding en de positie van de rechter in de rechtsstaat tegenover regering en parlement?

In het navolgende wil ik aan deze twee vragen aandacht besteden. Daarbij staat de vraag naar de waarborgfunctie van de machtenscheiding in de Grondwet (Gw) centraal. Aan de orde is in hoeverre een wetgevingsbevel van de rechter afbreuk doet aan de in de Grondwet verankerde onafhankelijke en zelfstandige positie van de Staten-Generaal. Daarnaast is het de vraag in hoeverre het Urgenda-arrest te rijmen is met het legaliteitsbeginsel van de rechtsstaat.

De stellingname van Baudet dat sprake zou zijn van een machtsgreep van de rechterlijke macht komt in de slotparagraaf aan de orde. Dat de rechter macht uitoefent, lijkt mij overigens, anders dan De Werd betoogt, buiten twijfel. In de rechtsstaat heeft de rechter tot taak geschillen te beslissen en strafbare feiten te berechten (art. 112 en $113 \mathrm{Gw}$ ), daarbij het handelen van het bestuur en de wetgever te controleren, en daarover een bindend oordeel te vellen. Dat hij daarbij geen beleidsmatige vergezichten presenteert, doet niet af aan het gegeven dat de rechter een van de drie belangrijkste overheidsfuncties in de staat vervult en derhalve staatsmacht uitoefent. Die staatsmacht is bovendien van overwegende betekenis gelet op de rechtsvormende taak van de rechter in de staat. Onder omstandigheden kan, zoals bij de andere twee staatsmachten het geval kan zijn, de vraag opkomen of de rechter een onjuist gebruik maakt van die machtspositie en zijn bevoegdheid overschrijdt. Of dat dan meteen leidt tot een machtsgreep, is natuurlijk een vraag van een andere orde.

\section{De machtenscheiding}

Zoals gezegd wordt in een aantal beschouwingen over het Urgenda-arrest sterk de nadruk gelegd op de rechtsvormende aspecten van rechtspraak, maar blijft het vraagstuk van de noodzaak tot verdeling en afbakening van staatsmacht voor de wetgever, het bestuur en de rechter nogal onderbelicht. Van Gestel en Loth gaan wat dat betreft in hun beschouwing over de legitimiteit van rechterlijke rechtsvorming nog een stapje verder. Zij betogen dat 'een hedendaagse trias politica' gewoon niet bestaat. 'De gedachte dat er thans slechts drie - grotendeels van elkaar gescheiden - staatsmachten zouden zijn is achterhaald', aldus Van Gestel en Loth. De auteurs wijzen op een toenemende diversiteit aan regelgevende, uitvoerende en geschilbeslechtende machten, en op een onderlinge verwevenheid in zowel hori-

4 J. Vranken, 'Consequenties van een versterking van de rechtsvormende taak van de Hoge Raad: talrijk, divers en soms vergaand', NJB 2009, p. 1082 e.v.; J.B.M. Vranken, 'Toeval of beleid? Over rechtsvorming door hoogste rechters', NJB 2000, p. 1 e.v.

5 Zie de bijdragen van Boogaard, Schutgens en Besselink in voetnoot 3. 
zontale als verticale zin. Bij een dergelijke vermenging van functies kan uiteraard moeilijk worden gesproken van een rechter die zich, zoals in het Urgenda-arrest, te activistisch opstelt. ${ }^{6}$

Het betoog van Van Gestel en Loth komt eigenlijk hierop neer dat het weinig zin heeft om tegenwoordig nog na te denken over constitutionele uitgangspunten voor de verdeling van taken en bevoegdheden tussen parlement, regering en rechterlijke macht. Alles loopt immers volgens deze auteurs anno 2021 door elkaar heen. Als we hen moeten geloven, is de staat heden ten dage organisatorisch in feite volgens een soort chaostheorie ingericht, waarin iedereen met iedereen en alles met alles verweven is.

De Hoge Raad onderkent in het Urgenda-arrest (gelukkig) wel enige ordening en taakverdeling tussen de staatsmachten in de staat, zij het dat een nadere beschouwing over bevoegdheidsverdeling in de context van de scheiding der machten, anders dan in de conclusie van de procureur-generaal bij de Hoge Raad, in het arrest zelf ontbreekt. ${ }^{7}$ De Hoge Raad plaatst het vraagstuk van taak- en bevoegdheidsverdeling tussen de staatsmachten volledig in de sleutel van het bevel tot wetgeving. De benadering ervan is als volgt. Voorop staat dat een fundamentele regel van de rechtsstaat eist dat de rechter de overheid, net als ieder ander, op vordering van een gerechtigde kan veroordelen tot nakoming van een verplichting. Verwezen wordt in dit verband naar het recht op effectieve rechtsbescherming van artikel 13 van het Europees Verdrag tot bescherming van de rechten van de mens en de fundamentele vrijheden (EVRM) en de bevoegdheid van de burgerlijke rechter op grond van artikel $112 \mathrm{Gw}$. In de rechtspraak van de Hoge Raad is echter voor wat betreft het nakomen van verplichtingen door de overheid een uitzondering gemaakt met betrekking tot het bevel tot wetgeving. ${ }^{8}$ Deze uitzondering berust op twee overwegingen. Ten eerste moet de rechter zich niet in de politieke besluitvorming begeven bij de totstandkoming van wetgeving. Ten tweede zou door een dergelijk rechterlijk bevel een regeling in het leven worden geroepen die ook voor anderen dan de procespartijen geldt. Hierbij tekent de Hoge Raad aan dat het een en ander niet impliceert dat de rechter in het geheel niet op het terrein van politieke besluitvorming mag komen. De rechter kan immers op grond van artikel $94 \mathrm{Gw}$ wetgeving buiten toepassing laten bij strijd met eenieder verbindende verdragsbepalingen. In de jurisprudentie van de Hoge Raad komt het daarnaast voor dat de rechter een verklaring voor recht kan uitspreken die erop neerkomt dat de overheid onrechtmatig handelt door geen wetgeving tot stand te brengen. ${ }^{9}$

In het Urgenda-arrest nuanceert de Hoge Raad vervolgens het uitgangspunt dat een rechterlijk bevel tot wetgeving niet tot de mogelijkheden behoort. De rechter dient zich namelijk niet door het geven van een wetgevingsbevel te mengen in de politieke besluitvorming met betrekking tot de opportuniteit van het tot stand brengen van wetgeving met een bepaalde, concreet omschreven inhoud. 'Het is,

6 Van Gestel \& Loth 2020, p. 886-887.

7 Zie de conclusie; ECLI:NL:PHR:2019:887, 5.42-5.64.

8 HR 21 maart 2003, ECLI:NL:HR:2003:AE8462 (Waterpakt).

9 Vgl. R.J.B. Schutgens, Onrechtmatige wetgeving (diss. Nijmegen), Deventer: Kluwer 2009, p. 85 e.v. 
gelet op de staatsrechtelijke verhoudingen, uitsluitend aan de betrokken wetgever zelf om te bepalen of wetgeving met een bepaalde inhoud tot stand komt. De rechter kan de wetgever dan ook geen bevel geven om wetgeving met een bepaalde inhoud tot stand te brengen', aldus de Hoge Raad. ${ }^{10}$ Deze nuancering van het Waterpakt-arrest betekent dat de Hoge Raad een wetgevingsbevel toelaatbaar acht '(...) teneinde een bepaald doel te bereiken, zolang dat bevel niet neerkomt op een bevel om wetgeving met een bepaalde, specifieke inhoud tot stand te brengen'. ${ }^{11}$ Wanneer de rechter volstaat met een algemeen bevel tot het nemen van maatregelen, doet zich volgens de Hoge Raad ook niet het bezwaar voor dat derden indirect gebonden worden aan de uitspraak. Immers, zo redeneert de Hoge Raad, de rechter bepaalt door zijn bevel niet de inhoud van de regeling; dat blijft voorbehouden aan de betrokken wetgever.

Met deze redenering verdedigt de Hoge Raad aldus zijn beslissing dat een algemeen wetgevingsbevel betreffende reductie van $\mathrm{CO}_{2}$-uitstoot van 25\% in 2020 gerechtvaardigd is.

De argumentatie van de Hoge Raad is mijns inziens eigenlijk nogal kort door de bocht. Zij getuigt van een eenzijdige kijk op de constitutionele verhoudingen tussen de staatsmachten. De Hoge Raad heeft, blijkens het voorgaande, vooral oog voor zijn eigen rol in de rechtsstaat, benadrukt het belang van effectieve rechtsbescherming, maar onderkent niet de belangen die ten aanzien van de andere staatsmachten in geding zijn. Een gefundeerd oordeel waarom de rechter niet een specifiek wetgevingsbevel mag geven, maar wel een algemeen wetgevingsbevel, ontbreekt. De Hoge Raad volstaat in dit verband slechts met een verwijzing naar een eerder arrest (SGP-arrest), waarbij het overigens twijfelachtig is of dat arrest als een dergelijke nuancering van het Waterpakt-arrest gelezen dient te worden. ${ }^{12}$

Om een beter beeld te krijgen van de constitutionele verhoudingen tussen de staatsmachten in de context van het al of niet toestaan van een wetgevingsbevel is het dienstig enige aandacht te besteden aan de rol van de wetgever (regering en parlement) en de rechter in de machtenscheiding. Vooraf moet daarbij worden opgemerkt dat het hier niet de bedoeling is om de machtenscheiding te benaderen vanuit de theorie van de trias politica van Montesquieu, zoals Van Gestel en Loth doen. ${ }^{13}$ Afgezien van de rechtshistorische betekenis heeft zo'n benadering betrekkelijk weinig waarde. Uitgangspunt is een positiefrechtelijke benadering. Bij deze benadering komt naar voren dat de Grondwet, evenals vele andere westerse constituties, ${ }^{14}$ van oudsher de machtenscheiding positiveert. Dat geldt niet alleen voor de functionele, maar ook voor de organisatorische machtenscheiding. De drie hoofdfuncties in de staat, wetgeving, bestuur en rechtspraak, kent de Grondwet

10 HR 20 december 2019, ECLI:NL:HR:2019:2006, r.o. 8.2.2-8.2.5.

11 HR 20 december 2019, ECLI:NL:HR:2019:2006, r.o. 8.2.5.

12 HR 9 april 2010, ECLI:NL:HR:2010:BK4549; vgl. Besselink 2020, p. 139 e.v.

13 In de conclusie van de P-G bij de Hoge Raad bij het Urgenda-arrest treft men eveneens enige summiere beschouwingen aan over de trias politica, zij het dat het bestaansrecht van de machtenscheiding hier niet ter discussie wordt gesteld, Zie r.o. 5.18 e.v.

14 Zie bijv. art. 20, tweede lid, van het Duitse Grundgesetz, en Article I, II en III van de US Constitution. 
toe aan de Staten-Generaal, de regering en de rechterlijke macht. ${ }^{15}$ Dit in de Grondwet gepositiveerde rechtsbeginse ${ }^{16}$ gaat ervan uit dat drie afzonderlijke, gelijkwaardige en zelfstandige - of: onafhankelijke - overheidsorganisaties in de staat de drie belangrijkste overheidsfuncties (in het centrale overheidsverband) uitoefenen. ${ }^{17}$

Het is in dit verband relevant om ook te verwijzen naar de aanhangige grondwetsherziening, waarbij een algemene bepaling ('De Grondwet waarborgt de grondrechten en de democratische rechtsstaat') als een nieuwe ongenummerde openingsbepaling aan de Grondwet wordt toegevoegd. De toelichtende stukken daarvan beschouwen de machtenscheiding als een van de vier kernelementen van de rechtsstaat. Zij houdt in dat '(...) drie categorieën van overheidsmacht, te weten wetgeving, uitvoering en rechtspraak, worden uitgeoefend door drie te onderscheiden machten' ${ }^{18}$ In het samenspel van bepalingen van hoofdstuk 2 (Regering), 3 (Staten-Generaal) en 6 (Rechtspraak) worden de drie machten en hun respectievelijke taken, bevoegdheden en onderlinge verhoudingen nader geduid. ${ }^{19}$

De Grondwet heeft aldus een waarborgfunctie, als het gaat om de rechtsstaat en de machtenscheiding. ${ }^{20} \mathrm{Zij}$ brengt op diverse plaatsen pregnant tot uitdrukking dat regering, Staten-Generaal en rechterlijke macht een zelfstandige en afzonderlijke positie ten opzichte van elkaar innemen. Het meest in het oog springt de zelfstandige en onafhankelijke positie van de rechterlijke macht, door in artikel $117 \mathrm{Gw}$ de rechterlijke onafhankelijkheid (rechtspositioneel) te waarborgen, en de bevoegdheid tot rechtspraak exclusief toe te vertrouwen aan de rechter (art. 112 en 113 $\mathrm{Gw}$ ). Regering en parlement mogen geen aandeel hebben in de uitoefening van de rechtspraakfunctie. Maar ook de zelfstandige en onafhankelijke positie van het parlement heeft van de grondwetgever van 1983 bijzondere aandacht gekregen. Grondwetsbepalingen inzake de parlementaire immuniteit (art. $71 \mathrm{Gw}$ ), de eigen werkwijze (reglementen van orde; art. $72 \mathrm{Gw}$ ), beëdiging (art. $60 \mathrm{Gw}$ ), benoeming van de voorzitter (art. $61 \mathrm{Gw}$ ), verbod van last (art. 67, derde lid, Gw), geloofsbrievenonderzoek (art. $58 \mathrm{Gw}$ ) en onverenigbare functies (art. $57 \mathrm{Gw}$ ) getuigen van een zelfstandige en onafhankelijke positie van het parlement en een duidelijke scheiding ten opzichte van de regering en de rechterlijke macht. ${ }^{21}$ In de Grondwet is verankerd dat de bevoegdheid om wetten vast te stellen exclusief is opgedragen aan de regering en de Staten-Generaal (art. 81 e.v. Gw). De rechter mag aldus geen aandeel hebben in de vaststelling van wetgeving.

Zie verder o.a. over de machtenscheiding in de oude Grondwet P.J. Oud, Het constitutioneel recht van het Koninkrijk der Nederlanden, deel II (2de druk), Zwolle: W.E.J. Tjeenk Willink 1970, p. 90; zie over de machtenscheiding als uitgangspunt van de democratische rechtsstaat M.C. Burkens, H.R.B.M. Kummeling, B.P. Vermeulen \& R.J.G.M. Widdershoven, Beginselen van de democratische rechtsstaat (8ste druk), Deventer: Wolters Kluwer 2017, p. 18-19; vgl. ook C.A.J.M. Kortmann, Constitutioneel recht (bew. 7de druk), Deventer: Wolters Kluwer 2016, p. 43 e.v.

16 A.K. Koekkoek (red.), De Grondwet (3de druk), Deventer: Kluwer 2000, p. 24.

17 Zie P.P.T. Bovend'Eert, 'Het rechtsbeginsel van de machtenscheiding', in: R.J.N. Schlössels, A.J. Bok, H.J.A.M. van Geest \& S. Hilligers, In beginsel. Over aard, inhoud en samenhang van rechtsbeginselen in het bestuursrecht, Deventer: Kluwer 2004, p. 243 e.v.

18 Kamerstukken II 2015/16, 34516, nr. 3, p. 6.

19 Kamerstukken II 2015/16, 34516, nr. 3, p. 6.

20 Kamerstukken II 2015/16, 34516, nr. 3, p. 3.

21 Zie hierover Kamerstukken II 1976/77, 14222, nr. 3, p. 3-4, 8, 11 en 17. 
De machtenscheiding in de Grondwet houdt, zoals bekend, geen absolute functionele en organisatorische scheiding in. Met name regering en parlement zijn in een parlementaire democratie nauw met elkaar verweven door allerlei checks and balances. ${ }^{22}$ Denk onder andere aan de samenwerking bij de totstandkoming van wetgeving en de begroting (art. 81 en $105 \mathrm{Gw}$ ), de ministeriële verantwoordelijkheid (art. $42 \mathrm{Gw}$ ), de ongeschreven vertrouwensregel en de Kamerontbinding (art. 64 $\mathrm{Gw}$ ). Controlemechanismen zijn ook te vinden in de verhouding tussen regering/ parlement en rechter. Denk aan de benoemingswijze van rechters door de regering (art. $117 \mathrm{Gw}$ ) en aan de controlefunctie van de rechter ten opzichte van bestuur en wetgever (art. 112, eerste en tweede lid, Gw).

De checks and balances moeten zorgen voor een evenwichtige verhouding tussen de staatsmachten. Dat betekent onder meer dat deze controlemechanismen niet zover mogen gaan dat het uitgangspunt van zelfstandigheid, onafhankelijkheid en gelijkwaardigheid van de drie staatsmachten ten opzichte van elkaar in gevaar komt. De praktijk leert dat zo nu en dan bij bepaalde ontwikkelingen in de moderne rechtsstaat nieuwe controlemechanismen in het leven worden geroepen die aan dit uitgangspunt niet of niet goed voldoen. De machtenscheiding kent in de praktijk zeker bepaalde defecten. ${ }^{23}$ Een bekend voorbeeld hiervan levert de huidige bestuursstructuur van de rechterlijke macht, waarin de Minister van Justitie en Veiligheid in de Wet op de rechterlijke organisatie (Wet RO) allerlei bevoegdheden heeft gekregen om toezicht te houden op de bedrijfsvoering en financiering van de rechtspraak. ${ }^{24}$ De minister stelt zich daarbij consequent op het standpunt dat hij verantwoordelijk is voor het goed functioneren van de rechterlijke macht en daarom toezicht uitoefent. Bij de totstandkoming van deze bestuursstructuur hebben de president van en procureur-generaal bij de Hoge Raad zich terecht krachtig (maar helaas vergeefs) verzet tegen dit controlemechanisme. De verantwoordelijkheid van de minister als medebegrotingswetgever, zo betoogden zij, kan op zichzelf niet wettigen dat hij de bevoegdheid zou moeten hebben om toezicht te houden op en invloed uit te oefenen ten aanzien van de wijze waarop de gevoteerde middelen door de rechterlijke macht worden besteed. ${ }^{25}$

Als het gaat om het wetgevingsbevel in het Urgenda-arrest rijst eveneens de vraag, maar dan vanuit een tegenovergesteld perspectief, of dit controlemechanisme verenigbaar is met het uitgangspunt van de machtenscheiding, waarin de drie staats-

22 Zie Kamerstukken II 2015/16, 34516, nr. 3, p. 6: 'Deze machtenscheiding heeft in Nederland in het bijzonder gestalte geregen in een stelsel van elkaar wederzijds controlerende, in evenwicht houdende organen (checks and balances).'

23 Maar dat hoeft nog geen reden te zijn om dit constitutionele uitgangspunt bij het grofvuil te zetten, zoals Van Gestel en Loth de facto doen.

24 Zie hierover Landelijk Tegenlicht, 'Toekomstvisie landelijk Tegenlicht', NJB 2018, p. 3224 e.v.; P. Bovend'Eert, 'Is de rechterlijke macht een inferieure staatsmacht?', NJB 2018, p. 3229 e.v.

25 Commentaar van 27 oktober 1999 van de president van en de procureur-generaal bij de Hoge Raad op de conceptwetsvoorstellen organisatie en bestuur gerechten en Raad voor de rechtspraak, NJB 2000, p. 1617 e.v. 
machten een zelfstandige, onafhankelijke en gelijkwaardige positie ten opzichte van elkaar behoren in te nemen. ${ }^{26}$

De volgende bedenkingen kunnen worden ingebracht. Ten eerste valt op dat het geven van een wetgevingsbevel door de rechter impliceert dat regering en Staten-Generaal ten opzichte van de rechter in een gezagsverhouding komen te verkeren. De wetgever krijgt een instructie van de rechter om een wet tot stand te brengen en dient deze op te volgen. Het wetgevingsbevel plaatst de rechter als het ware boven de wetgever. Een door de rechter te geven opdracht staat daarmee op gespannen voet met het uitgangspunt van de machtenscheiding dat regering en parlement zelfstandig en onafhankelijk hun wetgevingsbevoegdheden uitoefenen, en ten opzichte van de rechter een zelfstandige en onafhankelijke positie innemen. Een bevelsrelatie is hiermee niet te rijmen.

Ten tweede gaat de Grondwet ervan uit dat regering en Staten-Generaal gezamenlijk exclusief de bevoegdheid uitoefenen om een wet vast te stellen (art. $81 \mathrm{Gw}$ ). Zoals regering en parlement zich niet hebben te mengen in de totstandkoming van een rechterlijke uitspraak, zo heeft de rechter geen bemoeienis bij de totstandkoming van wetten. De rechter speelt daarin geen enkele rol, ${ }^{27}$ ook niet als het gaat om de vraag of de wet wel op de in de Grondwet voorgeschreven wijze tot stand is gekomen. ${ }^{28}$ Besluiten om een wetsvoorstel op te stellen, in te dienen, aanhangig te maken, te wijzigen, in te trekken, aan te nemen of te verwerpen komen al naar gelang toe aan fractievoorzitters en fracties bij de kabinetsformatie, aan ministers, de regering, Tweede Kamerleden, de Tweede Kamer en de Eerste Kamer. ${ }^{29}$ De beslissingen en besluiten zijn anders gezegd opgedragen aan politieke ambtsdragers. Dat is overigens geen willekeurige keuze. In de democratische rechtsstaat en de parlementaire democratie is de vaststelling van wetten een aangelegenheid van het democratisch gekozen parlement tezamen met de regering, waarvan de ministers verantwoording schuldig zijn aan het parlement en het vertrouwen behoeven van dat parlement. ${ }^{30}$ Het toekennen van wetgevingsbevoegdheden, zoals een wetgevingsbevel, aan de niet democratisch gelegitimeerde rechter, behorend tot een andere staatsmacht, leidt ertoe dat een vreemde eend in de bijt deelneemt aan het wetgevingsproces. ${ }^{31}$

Zie over machtenscheiding en wetgevingsbevel Schutgens 2009, p. 252 e.v.; G. Boogaard, Het wetgevingsbevel. Over constitutionele verhoudingen en manieren om een wetgever tot regelgeving aan te zetten (diss. Amsterdam UvA), Oisterwijk: Wolf Legal Publishers 2013, p. 61 e.v.; Van der Hulle 2020, p. 232 e.v.

27 Afgezien van de mogelijkheid dat rechtscolleges, zoals de Hoge Raad, in voorkomende gevallen een advies uitbrengen over een wetsvoorstel, met name wanneer zo'n voorstel de organisatie of werkwijze (procesrecht) van de rechterlijke macht raakt.

28 Aldus oordeelde de Hoge Raad in HR 27 januari 1961, ECLI:NL:HR:1961:AG2059 (Van den Bergh).

29 De Koning blijft hier buiten beschouwing.

30 Kamerstukken II 2015/16, 34516, nr. 3, p. 5.

31 Een bijzonder constitutioneel hof, zoals het Bundesverfassungsgericht in de BRD, zou wellicht ingrijpende wetgevingsbevoegdheden kunnen hebben vanwege zijn functie om erop toe te zien dat ook de politieke ambten in de wetsprocedure zich aan de Grondwet houden. Daarvan is in de $\mathrm{Ne}$ derlandse verhoudingen echter geen sprake. 
In het Waterpakt-arrest had de Hoge Raad nog wel oog voor deze rolverdeling. Hij overwoog:

'Wetten in formele zin worden ingevolge artikel $81 \mathrm{Gw}$ vastgesteld door de regering en de Staten-Generaal, waarbij de vraag of, wanneer en in welke vorm een wet tot stand zal komen, moet worden beantwoord op grond van politieke besluitvorming en afweging van de erbij betrokken belangen. De evenzeer op de Grondwet berustende verdeling van bevoegdheden van de verschillende staatsorganen brengt mee dat de rechter niet vermag in te grijpen in die procedure van politieke besluitvorming. ${ }^{32}$

In het Urgenda-arrest lijkt de Hoge Raad zich niet meer zo bewust te zijn van deze implicaties van artikel 81 Gw. De Hoge Raad acht een specifiek wetgevingsbevel niet, maar een algemeen wetgevingsbevel nu wel toelaatbaar. Het moge duidelijk zijn, gelet op het voorgaande, dat noch een specifiek, noch een algemeen wetgevingsbevel van de rechter te rijmen is met het constitutionele uitgangspunt van de machtenscheiding en de exclusieve bevoegdheidstoedeling aan regering en Staten-Generaal krachtens artikel $81 \mathrm{Gw}$.

Overigens blijft nogal mistig wat het onderscheid is tussen een algemeen en specifiek wetgevingsbevel. Is een algemeen wetgevingsbevel om $\mathrm{CO}_{2}$-uitstoot in 2020 te reduceren met $25 \%$ niet eigenlijk heel specifiek? En wat is eigenlijk precies het verschil tussen een algemeen wetgevingsbevel en een specifiek wetgevingsbevel? Een antwoord op die vraag is aan de hand van het Urgenda-arrest niet te geven. ${ }^{33}$

Ten derde is het de vraag of een wetgevingsbevel, algemeen dan wel specifiek, niet een ongeoorloofde inbreuk maakt op de genoemde zelfstandige en onafhankelijke positie van de Staten-Generaal. Hiervoor was sprake van een aantal bijzondere constitutionele waarborgen voor de zelfstandigheid en onafhankelijkheid van de Staten-Generaal en hun leden. Die zelfstandigheid en onafhankelijkheid komen in het geding wanneer aangenomen moet worden dat de rechter de staat, en daarmee de Kamers en leden van de Staten-Generaal kan bevelen om wetgeving tot stand te brengen. Hoe is zo'n wetgevingsbevel te rijmen met het verbod van last (art. 67 $\mathrm{Gw}$ ), dat veronderstelt dat Kamerleden geen bindend maar een vrij mandaat hebben en naar eigen inzicht stemmen over wetgeving? Houdt zo'n wetgevingsbevel dan in dat de Kamers verplicht zijn wetsvoorstellen aan te nemen en dat de leden verplicht zijn voor te stemmen? Vanuit het perspectief van de machtenscheiding en genoemde grondwettelijke waarborg kan dat, denk ik, bepaald niet de bedoeling zijn. Ook het in de Grondwet vastgelegde uitgangspunt dat de Kamers autonoom hun werkwijze regelen en zelf beslissen over te behandelen aangelegenheden (art. $71 \mathrm{Gw}$ ) is niet goed te rijmen met een rechterlijk wetgevingsbevel. Voorts is de grondwettelijke waarborg van de parlementaire immuniteit in dit verband problematisch. Die immuniteit veronderstelt dat Kamerleden niet in rechte aanspreekbaar zijn voor hun bijdragen aan parlementaire debatten. Handhaving van een wet- 
gevingsbevel lijkt aldus af te stuiten op artikel $71 \mathrm{Gw}$. Of is het de bedoeling om de stemmingen van het vereiste van parlementaire immuniteit uit te sluiten, zodat de rechter Kamerleden kan aanspreken op hun weigering om een wetsvoorstel aan te nemen ter uitvoering van een wetgevingsbevel? In het Urgenda-arrest besteedt de Hoge Raad geen aandacht aan al deze bijzondere grondwettelijke waarborgen voor (de leden van) de Staten-Generaal in het kader van de machtenscheiding. De Hoge Raad heeft zoals gezegd helaas slechts oog voor artikel 13 EVRM en artikel $112 \mathrm{Gw}$, een veel te beperkt perspectief als het gaat om de vraag of een wetgevingsbevel in de machtenscheiding aanvaardbaar is.

Dat ook een algemeen wetgevingsbevel in de wetgevingspraktijk daadwerkelijk afbreuk doet aan de grondwettelijk gewaarborgde autonomie van regering en Staten-Generaal bij de vaststelling van wetgeving illustreert de nasleep van het Urgen$d a$-arrest. Inmiddels is onder verwijzing naar het reductiebevel van de Hoge Raad een wetsvoorstel in behandeling dat kolencentrales een productiebeperking oplegt in de aanloop naar een verbod van energie op kolen dat vanaf 2030 gaat gelden. ${ }^{34}$ Het voorbeeld maakt duidelijk dat er alleszins mogelijkheden zijn in de praktijk om in het kader van algemeen-belangacties via de rechter door een algemeen wetgevingsbevel af te dwingen dat regering en Staten-Generaal verplicht worden op allerlei beleidsterreinen al of niet tijdelijke (beleidsinstrumentele) wetgeving tot stand te brengen teneinde bepaalde beleidsdoelen te bereiken. Het opleggen van dergelijke verplichtingen is niettemin, zoals uit het voorgaande blijkt, ongrondwettig.

Ten slotte moet nog een opmerking worden gemaakt met betrekking tot de stellingname van de Hoge Raad in het Urgenda-arrest dat ten aanzien van de algemene regel dat de rechter ook bevoegd is de overheid te verplichten tot nakoming, in beginsel een uitzondering wordt gemaakt voor een wetgevingsbevel, nu door zo'n rechterlijk bevel een regeling in het leven wordt geroepen die ook voor anderen dan de procespartijen geldt. De Hoge Raad acht tegen deze achtergrond een wetgevingsbevel met een bepaalde inhoud niet toelaatbaar. Een algemeen wetgevingsbevel is volgens de Hoge Raad daarentegen wel mogelijk.

Waarom een specifiek wetgevingsbevel niet en een algemeen wetgevingsbevel wel toelaatbaar is, is mij niet duidelijk. De nuance ontgaat me. In beide gevallen gaat het immers om een bevel een regeling in het leven te roepen die ook voor anderen dan procespartijen geldt. Ook dit aspect raakt de machtenscheiding. Het is aan de wetgever (art. $81 \mathrm{Gw}$ ), of aan andere regelgevers (vergelijk art. 89 en $127 \mathrm{Gw}$ ), om algemene regels vast te stellen. Het is aan de rechter om concrete geschillen tussen procespartijen te beslechten (art. 112 en $113 \mathrm{Gw}$ ). De rechter is niet bevoegd om beslissingen te nemen die een algemene werking hebben. Artikel 12 van de Wet algemene bepalingen (Wet $\mathrm{AB}$ ) scherpt de rechter in het verlengde hiervan in dat hij niet bij wege van algemene verordening, dispositie of reglement uitspraak doet in zaken die aan zijn beslissing zijn onderworpen. Ook dit artikel brengt het machtenscheidingsprincipe tot uitdrukking. Het verbiedt de rechter aan zijn uitspraak algemene werking te geven. Opzoomer merkte in zijn klassieke commentaar bij de 
Wet $A B$ treffend op dat het geven van een wettelijk voorschrift, in welke vorm dan ook, altijd uitsluitend het werk van de wetgevende macht blijft. Het kan nooit tot de taak van de rechterlijke macht behoren. 'De wetgevende macht kan zich niet de handen binden en van haar eigen recht van oordeel en beslissing afstand doen', aldus Opzoomer. ${ }^{35}$

\section{Het legaliteitsbeginsel in de rechtsstaat}

Hiervoor werd opgemerkt dat de regering in de toelichting bij het voorstel tot grondwetsherziening inzake een algemene bepaling in de Grondwet de machtenscheiding als een van de kernelementen van de democratische rechtsstaat beschouwt. Een ander kernelement betreft het legaliteitsbeginsel, dat volgens die toelichting inhoudt dat machtsuitoefening door de overheid alleen mag plaatsvinden op grond van een wet en binnen de door het recht getrokken grenzen. ${ }^{36}$

In de democratische rechtsstaat moet overheidsoptreden een grondslag hebben in de wet. ${ }^{37}$ De overheid moet overeenkomstig de wet handelen. Dit legaliteitsbeginsel geldt niet alleen voor het bestuur of de wetgever die gebonden is aan de Grondwet, maar ook voor de rechter. Zijn rechtspraak moet wettig zijn. In de rechtsstaat veronderstelt het legaliteitsbeginsel dat een democratisch gelegitimeerde wetgever - regering en Staten-Generaal - in de wet de grondslag verschaft (eventueel met de mogelijkheid van delegatie) voor burgers bindende regels, voorafgaand aan overheidsoptreden. De vaststelling van ongeschreven rechtsregels/rechtsvorming in de rechtspraak van de rechter voldoet niet aan dit basiselement van de rechtsstaat, tenzij de rechter de wet toepast en daarbij recht vormt op basis van (het stelsel van) de wet. De gebondenheid van de rechter aan de wet is vooralsnog niet in de Grondwet verankerd, maar berust op artikel 11 Wet $A B$ : 'De regter moet volgens de wet regtspreken; hij mag in geen geval de innerlijke waarde of billijkheid der wet beoordelen.' Artikel 11 Wet AB sluit niet uit dat de rechter zelfstandig de wet uitlegt. De rechter is vrij in de interpretatie van wettelijke regels. Niettemin is de binding van de rechter aan de wet een onmisbaar element van het legaliteitsbeginsel. Zoals het onaanvaardbaar is dat het bestuur zich onttrekt aan het legaliteitsbeginsel en naar eigen inzicht/willekeur handelt zonder binding aan de wet, zo is het onaanvaardbaar in een democratische rechtsstaat aan te nemen dat de rechter niet onderworpen is aan de wet en naar eigen inzicht nieuwe rechtsregels kan scheppen en nieuw recht vormen zonder een grondslag in de wet. Juist door de binding van de rechter aan de wet is het te verdedigen in een democratische rechtsstaat dat deze overheidsinstantie, hoewel democratisch niet gelegitimeerd en 'onverantwoordelijk', overheidsmacht uitoefent.

36 Kamerstukken II 2015/16, 34516, nr. 3, p. 6. Zie uitgebreid P.P.T. Bovend'Eert, 'Wetgever, rechter en rechtsvorming. "Partners in the business of law?", RMThemis 2009, p. 145 e.v.

37 Daaronder kunnen bijv. ook verdragsbepalingen worden verstaan. 
In zijn 'legendarische' afscheidsrede in 2000 heeft Martens aan de hand van de jurisprudentie van de Hoge Raad de (grenzen van de) rechtsvormende taak van de rechter op heldere wijze geschetst. Martens onderscheidt drie varianten van rechtsvorming: (1) de wetstoepassing (uitwerken van vage of open rechtsnormen in het geschreven recht), (2) de vorming van nieuw recht binnen het stelsel van de wet (criterium Quint/Te Poel) en (3) de vorming van nieuw recht buiten het stelsel van de wet. ${ }^{38}$ De eerste twee varianten leveren in de context van het legaliteitsbeginsel geen problemen op. De derde variant heeft volgens Martens betrekking op de situatie waarin een wettelijk voorschrift onverenigbaar is met een verdragsbepaling en de rechter het wettelijk voorschrift buiten toepassing zal moeten laten (art. $94 \mathrm{Gw}$ ). De rechter zal dan met het oog op de 'rule of law' en het belang van effectieve rechtsbescherming deze leemte moeten opvullen. Hij gaat daarbij eerst na of hij effectieve rechtsbescherming kan bieden door het wettelijk voorschrift buiten toepassing te laten. Is dat niet mogelijk, dan kan de rechter in het rechtstekort voorzien door zelf nieuw recht te vormen of de vorming van nieuw recht voorlopig over te laten aan de wetgever. ${ }^{39}$ Martens wijst daarbij weliswaar op de traditioneel terughoudende rol van de rechter in het staatsbestel, maar een ingrijpen door de rechter is niettemin met een beroep op genoemde effectieve rechtsbescherming gerechtvaardigd, als de wetgever geen oplossing voor het rechtsprobleem biedt.

In deze beschouwing van Martens en in de daaraan ten grondslag liggende jurisprudentie van de Hoge Raad ontbreekt aldus een onvoorwaardelijke binding van de rechter aan de wet. De wetgever heeft weliswaar het primaat, maar de rechter is bevoegd onder omstandigheden nieuw recht te vormen zonder een grondslag in de wet. De Hoge Raad wijst evenals Martens ter rechtvaardiging in het bijzonder op het belang van effectieve rechtsbescherming.

Het belang van het bieden van effectieve rechtsbescherming aan de burger kan echter mijns inziens in een rechtsstaat niet een rechtvaardiging zijn voor de rechter om buiten het stelsel van de wet naar eigen inzicht, overtuiging of geweten recht te spreken. Zonder rechtmatigheidscriteria, ontleend aan de wet of het stelsel van de wet, kan de rechter per definitie geen beslissing nemen. In dat opzicht is de rechter slechts tot het bieden van effectieve rechtsbescherming gehouden, als hij binnen het stelsel van de wet een rechtmatigheidsoordeel kan geven. Ontbreekt dat juridische aanknopingspunt, dan vervalt de rechter in de onmogelijke situatie dat hij slechts een politiek of beleidsmatig oordeel aan zijn beslissing ten grondslag kan leggen, hetgeen in een rechtsstaat nu juist niet aanvaardbaar is gelet op het legaliteitsbeginsel.

De vraag is hoe het Urgenda-arrest vanuit dit rechtsstatelijk perspectief beoordeeld moet worden. Op het eerste oog lijkt de Hoge Raad het geschil te beslissen binnen het stelsel van de wet (variant 1 of 2). De Hoge Raad past artikel 2 EVRM (recht op leven) en artikel 8 EVRM (recht op gezinsleven) toe op het geschil tussen Urgenda 
en de Staat. Daarbij volgt de Hoge Raad het Europees Hof voor de Rechten van de Mens (EHRM), dat al eerder in zijn jurisprudentie zorgplichten voor de overheid inzake het treffen van milieumaatregelen heeft aangenomen. ${ }^{40}$ Daaruit leidt de Hoge Raad in algemene zin af dat de artikelen 2 en 8 EVRM voor de Staat de zorgplicht meebrengen om maatregelen te nemen tegen een gevaarlijke klimaatverandering. ${ }^{41}$ Vervolgens moet de Hoge Raad de vraag beantwoorden tot welke concrete verplichting de Staat gehouden is. Dient de Staat zich te houden aan de 25-40\%-reductiedoelstelling voor $\mathrm{CO}_{2}$-uitstoot en dient de Staat in 2020 ten minste een reductiedoelstelling van $25 \%$ te realiseren?

Bij de beantwoording van deze vragen ontspoort volgens mij het arrest van de Hoge Raad, in die zin dat het pad verlaten wordt waarbij de rechter volgens (het stelsel van) de wet rechtspreekt. De Hoge Raad merkt weliswaar eerst terecht op dat de beantwoording van genoemde vragen in beginsel tot het politieke domein behoort, maar hij voegt hieraan vervolgens toe dat er onder omstandigheden sprake kan zijn van zodanig duidelijke opvattingen, afspraken en/of consensus in internationaal verband en in klimaatwetenschappelijk verband, dat de rechter kan vaststellen wat in elk geval is aan te merken als de minimale 'fair share'-verplichting van de Staat. ${ }^{42}$ Het gevolg hiervan is dat de Hoge Raad zijn oordeel niet baseert op rechtsnormen die een wettelijke grondslag hebben, maar op wetenschappelijke en politieke opvattingen, afspraken en (vermeende) consensus. ${ }^{43}$

De Hoge Raad volgt daarmee een benadering die niet verenigbaar is met het legaliteitsbeginsel van de rechtsstaat. Hij past niet de wet en het daarop gebaseerde recht toe (art. 11 Wet $\mathrm{AB}$ ), maar stelt daarvoor in de plaats de toepassing van politieke en wetenschappelijke inzichten. Uiteindelijk overweegt de Hoge Raad dat de Staat onvoldoende heeft onderbouwd dat het verantwoord is om voor 2020 minder reductie dan $25 \%$ te realiseren. En daarmee is er dan volgens de Hoge Raad voldoende grond om de Staat te verplichten zich aan een reductiedoelstelling van minimaal $25 \%$ te houden. Terecht stelt Besselink hierbij de (retorische) vraag: '[Z]ijn er juridische aanwijzingen dat $25 \%$ wel genoeg is om het recht op leven en privacy te beschermen maar een lager percentage niet?'44

Het Urgenda-arrest kent aldus vanuit rechtsstatelijk perspectief een serieus juridisch defect. Een bruikbare rechtsnorm om het geschil te beslissen ontbreekt. De

40 Zie HR 20 december 2019, ECLI:NL:HR:2019:2006, r.o. 5.1 e.v.

41 Zie HR 20 december 2019, ECLI:NL:HR:2019:2006, r.o. 5.10.

42 Zie HR 20 december 2019, ECLI:NL:HR:2019:2006. Vgl. hierover Boogaard \& Schutgens 2020, p. 889-890.

43 Ten tijde van het arrest van de Hoge Raad was er wereldwijd overigens allerminst consensus over klimaatverandering en -maatregelen. De regering van de VS (grootste economie ter wereld!) bijv. nam nog een sterk afwijkend standpunt in. Andere buitenlandse regeringen waren of zijn (vgl. de Britse regering) sceptisch, en in sommige landen is het duidelijk dat de regering de facto slechts lippendienst bewijst aan klimaatakkoorden en de facto verdergaat met klimaatbedreigende activiteiten. Er is wat dat betreft nog veel werk aan de winkel om daadwerkelijk enige consensus (en concrete resultaten) te bereiken. Enkele rechtsoverwegingen in het arrest van de Hoge Raad hebben tegen deze achtergrond een hoog academisch, maar weinig realistisch gehalte.

44 Besselink 2020, p. 143. Vgl. ook over 'juridische vaagheid en politieke gevoeligheid', Boogaard \& Schutgens 2020, p. 889-890. 
rechter had dit gegeven moeten onderkennen en de vordering van Urgenda afwijzen.

\section{Slot. Machtsgreep van rechters?}

Op het Urgenda-arrest valt vanuit een oogpunt van de machtenscheiding en het legaliteitsbeginsel van de rechtsstaat veel aan te merken, zo volgt uit het voorgaande. Maar daarmee is natuurlijk niet gezegd dat de rechter in Nederland zich vaak weinig gelegen laat liggen aan deze belangrijke constitutionele rechtsbeginselen. In het algemeen is de rechter terughoudend bij de beoordeling van geschillen die sterk in de politieke sfeer liggen en de verdeling van bevoegdheden tussen de staatsmachten raken. Tegenover het Urgenda-arrest staan veel andere arresten, waarin de Hoge Raad vanuit een oogpunt van machtenscheiding en rechtsstaat wel prudent oordeelt. Het eerdergenoemde Waterpakt-arrest is zo'n voorbeeld. In het Afghanistan-arrest overweegt de Hoge Raad over de vorderingen van actiegroepen om de Staat te verbieden mee te werken aan de inzet van strijdkrachten in Afghanistan, dat deze vorderingen betrekking hebben op vragen betreffende het beleid van de Staat op het gebied van de buitenlandse politiek en defensie, welk beleid in sterke mate afhangt van politieke afwegingen in verband met de omstandigheden van het geval. De Hoge Raad voegt hieraan toe:

'[H] et is, ook waar het het geweldverbod betreft, niet aan de burgerlijke rechter om deze politieke afwegingen te maken en op verlangen van een burger de Staat (de regering) bepaalde handelingen ter uitvoering van politieke besluitvorming op het gebied van het buitenlands beleid of defensie te verbieden of hem te gelasten op dit gebied een bepaalde gedragslijn te volgen. ${ }^{\text {'5 }}$

Een weinig gelukkig arrest, zoals het Urgenda-arrest, betekent niet meteen een bedreiging van de rechtsstaat. Het arrest kan wel een riskant precedent opleveren, niet alleen omdat de Hoge Raad daarin een wetgevingsbevel alsnog toelaatbaar acht, maar ook omdat het nu eenmaal vaker voorkomt dat de rechter op vordering van actiegroepen gevraagd wordt een sterk politiek getint geschil te beslissen, waarbij bruikbare rechtsnormen met een wettelijke grondslag om het geschil te beslissen ontbreken. Het is tegen die achtergrond zaak dat de Hoge Raad zich bezint op zijn jurisprudentie over wetgevingsbevelen, die naar mijn mening ongrondwettig is. De Hoge Raad dient meer oog te hebben voor de staatsrechtelijke verhouding tussen regering, parlement en rechter in de machtenscheiding en de rechtsstaat. 